\title{
Effect of Cold Stress on Some Blood Parameters of Sheep and Goats
}

\author{
Jassim E. AL-Musawi', Shaker A. Hassan², Sundus F. Muhammad ${ }^{3}$ \\ ${ }^{1}$ Department of Public Health, College of Veterinary Medicine, Baghdad University, Iraq \\ ${ }^{2,3}$ Department of Animal Production, College of Agriculture, Baghdad University, Iraq
}

\begin{abstract}
This study was conducted to investigate the effect of age and breed on the hematological parameters and blood biochemistry of domestic sheep and goats (male) under winter cold. Healthy animals were chosen $(n=10$ each breed) reared under the local breeding conditions during cold winter, a season characterized with a relatively low pasture. Animals were divided into four groups,

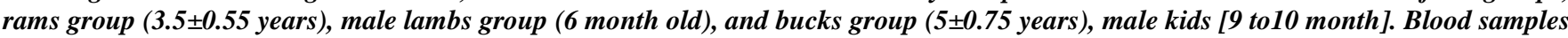
were collected in January when the pasture level was at its minimum. The Results presents an overview of hematological parameters and factors affecting their values. Results of hematological parameters showed significant $(P<0.05)$ differences between breed of animals. On the other hand, the kids group had significantly $(P<0.05)$ lesser packed cell volume PCV\% than the bucks group, while other parameters were similar.But, the white blood cell count (WBC) was significantly higher in the goat groups and the result of buck group was best than kids group. The values obtained for serum total protein was significantly lower $(P<0.05)$ for rams and buck groups, while the values obtained for serum urea concentration was significantly $(P<0.05)$ higher for rams and buck groups. In conclusion this study has reported hematological and serum biochemical values which could serve as baseline information for comparison in conditions of nutrient deficiency, physiological and health status of local male sheep and goats.
\end{abstract}

Keywords: Hematological parameters, urea, lambs, rams, kids, goats

\section{Introduction}

Small ruminants are very important farm animals in Iraq, especially the Awasi breed,and the Hematological studies are of ecological and physiological interest in helping to understand the relationship of blood characteristics and the environment [1].One of massive problems coating on the farm animals are seasonal and the nutrition availability [2], and the domestic animals fed natural pasture is a major factor that can negatively affect animal performance[3]. The feed is an important factor affecting on the biological indicators. Also, the level of dietary forage was found to exert much greater influence on digestibility and blood metabolites in small ruminants [4]. When feed is poor in proteins the concentration of total proteins in the body is reduced [5]. In addition the feed of poor fatty substances leads to a low concentration of cholesterol in the blood [6]. Likewise blood cholesterol when increased destruction of fats[7]. Also the animal age has a clear impact on these indicators or parameters [1 and 8]. Moreover, [3 and 9] reported that the season has significant impact on these biological indicators, cholesterol level rises in the winter and declines in summer, The changes in these parameters have been studied in cattle and sheep[10].However, there is a major variation in the hematological and biochemical parameters between breeds of farm animals[11], furthermore, the variations in some biochemical parameters were evidenced in different breeds of animals, which are certainly related to genetic and adaptation origins[12,13and 14]. So that they can be useful in the selection of animals that are genetically resistant to certain diseases and environmental conditions $[15,16]$. The purpose of this study was to evaluate some blood parameters indicators in relation breed and age, during cold winter, which is characterized with low pasture.

\section{Materials and Methods}

Healthy indigenous goat and Awassi sheep, which are well adapted to the ecological factors of the location, were selected. The farm is located in Agriculture Faculty/ University of Baghdad, at Jadria region in Baghdad. The cold season usually extends from December till March. The presence of herbaceous vegetation begins from late spring and summer. Animals were fed only on natural pasture or implantation grown on the farm returning to Agriculture College with a large surface area, which holds varieties of herbs, leaves' trees, grains and drink natural water. The ages, weights and the physiological states of animals were identified in cooperation with the farm owner and a veterinarian. Thus, four groups $(\mathrm{n}=10$ each group)were taken as follows, rams $(3.5 \pm 0.55$ years $)$, male lambs [6 month old], and Bucks ( $5 \pm 0.75$ years)and male kids ( 9 to 10 month old). However, the main weights of animals' were $90.6 \pm 81,21.6 \pm 2.5,68.7 \pm 2.2$ and $40.5 \pm 3.6 \mathrm{Kg}$ for rams, male lambs, Bucks and male kids respectively.

Samples were taken in winter when temperature reached 11 $\mathrm{C}^{\circ}$ and natural pasture was at its minimum availability in this period of the year. Blood was withdrawn in the morning of January 2016 from jugular vein before animals have any feed, $3 \mathrm{ml}$ of the blood samples was collected into plastic tubes containing EDTA for hematological studies., The remaining $7 \mathrm{ml}$ of blood samples was deposited in anticoagulant free plastic tube which were subjected to centrifugation at 4000 RPM. during 10 minutes . The serum samples were stored at $-20^{\circ} \mathrm{C}$ for biochemical studies. Total erythrocytes counts and total leukocytic counts were determined by using of Hemocytometer (Neubaeur counting chamber) and $\mathrm{Hb}$ concentration was determined by Shale's(acid haematin) method, Packed cell volume (PCV)was determined by microhematocrit, Mean Corpuscular Hemoglobin Concentration (MCHC), Mean

Volume 6 Issue 1, January 2017

www.ijsr.net

Licensed Under Creative Commons Attribution CC BY 


\section{International Journal of Science and Research (IJSR) \\ ISSN (Online): 2319-7064 \\ Index Copernicus Value (2015): 78.96 | Impact Factor (2015): 6.391}

Corpuscular Hemoglobin (MCH), Mean Corpuscular Volume (MCV) values were calculated[17, 18]. The serum was used to estimate glucose, total proteins, cholesterol, triglycerides, and urea by using commercial kits "SPINREACT", Spain. The experimental procedures were carried out according to the National Institute of Health Guidelines for Animal Care and approved by the Ethics Committee of our Institution [19] and [20]. The statistical analysis: The values are given as mean $\pm \mathrm{SE}$ and $\mathrm{P}<0.05$ was considered statistically significant. The data were analyzed by students' $t$-test using SPSS (Version 22).

\section{Results and Discussion}

The effect of cold winters on mean hematologicaland serum biochemical values of sheep and goats male are shown in (Tables 1 and 2)The results concerned with hematological values are presented in (Table 1). They show no significant differences in the hematological values for all parameters of the sheep groups. Nevertheless the goat groups show that the bucks group had significantly highest PCV(30.50\%)as compared with kids group.The Hemoglobin values ranged from $9.56 \mathrm{~g} / \mathrm{dl}$ for kids group to 8.93 million/ $\mu$ lin bucks group. The RBC values ware observed to be highest in the bucks group as compared with kids group (10.15 and 9.39 $\mathrm{g} / \mathrm{dl})$ respectively. Mean corpuscular hemoglobin (MCH), (MCV) values mean corpuscular hemoglobin concentration (MCHC) and mean white blood cell count (WBC)ware significantly higher for sheep groups as compared with goat group.

Table 1: Effect of cold stress on hematological values in sheep and Goats(males),(mean \pm S.E.)

\begin{tabular}{|c|c|c|c|c|}
\hline Parameters & Lambs & Rams & Kids & Bucks \\
\hline PCV \% & $35.00 \pm 0.84^{\mathrm{a}}$ & $\begin{array}{c}35.00 \pm \\
0.85^{\mathrm{a}}\end{array}$ & $\begin{array}{c}28.00 \\
\pm 0.85^{\mathrm{c}}\end{array}$ & $\begin{array}{c}30.50 \\
\pm 0.83^{\mathrm{b}}\end{array}$ \\
\hline $\mathrm{Hb}[\mathrm{g} / \mathrm{dl}]$ & $12.33 \pm 1.16$ & $\begin{array}{l}12.33 \\
\pm 1.25\end{array}$ & $\begin{array}{c}9.56 \\
\pm 0.17\end{array}$ & $\begin{array}{c}8.93 \\
\pm 0.47\end{array}$ \\
\hline $\begin{array}{c}\mathrm{RBC} \\
{[\text { million} / \mu \mathrm{l}]}\end{array}$ & $8.88 \pm 0.71$ & $\begin{array}{c}8.52 \\
\pm 0.58\end{array}$ & $\begin{array}{c}9.39 \\
\pm 0.36\end{array}$ & $\begin{array}{r}10.15 \\
\pm 1.07\end{array}$ \\
\hline $\mathrm{MCH}[\mathrm{Pg}]$ & $14.06 \pm 1.82^{\mathrm{a}}$ & $\begin{array}{c}14.41 \\
\pm 0.75^{\mathrm{a}}\end{array}$ & $\begin{array}{c}10.20 \\
\pm 0.21^{\mathrm{b}}\end{array}$ & $\begin{array}{c}9.04 \\
\pm 1.28^{\mathrm{b}}\end{array}$ \\
\hline $\mathrm{MCV}[\mathrm{fl}]$ & $40.01 \pm 3.69^{a}$ & $\begin{array}{c}40.01 \\
\pm 3.69^{\mathrm{a}}\end{array}$ & $\begin{array}{c}30.61 \\
\pm 1.96^{\mathrm{b}}\end{array}$ & $\begin{array}{c}30.79 \\
\pm 3.51^{\mathrm{b}}\end{array}$ \\
\hline $\mathrm{MCHC} \%$ & $34.91 \pm 1.18^{\mathrm{a}}$ & $\begin{array}{c}35.17 \\
\pm 0.36^{\mathrm{a}}\end{array}$ & $\begin{array}{c}33.51 \\
\pm 1.17^{\mathrm{a}}\end{array}$ & $\begin{array}{c}29.31 \\
\pm 1.18^{\mathrm{b}}\end{array}$ \\
\hline $\begin{array}{c}\text { WBC }\left[\mathrm{x} 10^{9}\right. \\
/ \mathrm{L}]\end{array}$ & $15.73 \pm 0.74^{b}$ & $\begin{array}{r}14.16 \\
\pm 1.79^{\mathrm{b}} \\
\end{array}$ & $\begin{array}{c}19.36 \\
\pm 0.91^{\mathrm{a}}\end{array}$ & $\begin{array}{c}21.00 \\
\pm 1.52^{\mathrm{a}} \\
\end{array}$ \\
\hline
\end{tabular}

abc, different letters in the same row denote significant differences between experimental groups at level $P<0.05$.

Packed cell volume (PCV)shows no differences between sheep groups, while in bucks was higher than obtained for kids.These findings are consistent with other studies[21, 22] which founds that change of PCV values in the goats may be attributed tothe effect of environmental temperature. High $\mathrm{PCV}$ values indicate either an increase in the number of circulating $\mathrm{RBC}$ or reduction in circulating plasma volume[23].Non significant differences were observed for Hemoglobin $(\mathrm{Hb})$ concentration in this study. Nevertheless, hematological traits especially PCV and $\mathrm{Hb}$ were correlated with nutritional status of the animal [24].
The results of the RBC count, show that there were no significant differences in this study,while the observed difference in adult and young goats suggested that the oxygen carrying capacity of the blood was high in adult goats, this is in agreement with the findings of $[25,26]$. Results also revealed that lesser Mean corpuscular hemoglobin $(\mathrm{MCH})$ and mean corpuscular hemoglobin concentration (MCHC)ware detected in bucks group as compared with kids and others groups.Similar finding was reported by many studies[27, 28and 29].The values of mean corpuscular hemoglobin $(\mathrm{MCH})$ and mean corpuscular hemoglobin concentration (MCHC)were influenced by many factors like management, age and climatic factors. Furthermore, the differences between those parameters referred to animals types. The total White Blood Cell (WBC) count was higher in goat groups as compared with the sheep groups these higher values refer to good development of gouts immune system. This result agree with [30] whom reported that the goats had well immune system. However, the results of the present study showed that higher total WBC counts in adult goats than in young goats which were in contrast to the study carried out by[11]. The higher values obtained in this study suggest well developed immune system of the adult goats.

Results in table2 show the impact of cold stress on some biochemical parameters.The significant differences were observed in some biochemical parameters. Thus the levels of total proteins was significantly $(\mathrm{P}<0.05)$ different in male lambs and kids as compared with rams and bucks respectively. Nevertheless, no changes were observed in glucose concentration between groups. While, urea concentrations were remarkably higher in rams and Buck than in lambs and kids. On the contrary, total cholesterol and triglyceride levels show inconsistency for breed and age.

Table 2: Effect of cold stress on the levels of biochemical parameters in sheep and Goats (males),(mean \pm S.E.)

\begin{tabular}{|c|c|c|c|c|}
\hline Parameters & Lambs & Rams & Kids & Bucks \\
\hline Total protein & 73.80 & 64.16 & 67.86 & 54.79 \\
g/l & $\pm 1.05^{\mathrm{a}}$ & $\pm 0.74^{\mathrm{b}}$ & $\pm 0.30^{\mathrm{b}}$ & $\pm 0.18^{\mathrm{c}}$ \\
\hline Glucose BG & 58.72 & 61.16 & 40.90 & 38.11 \\
$\mathrm{mg} / 100 \mathrm{ml}$ & \pm 1.84 & \pm 2.33 & \pm 4.60 & \pm 3.54 \\
\hline Urea BUN & 36.33 & 45.66 & 33.66 & 41.66 \\
$\mathrm{mg} / 100 \mathrm{ml}$ & $\pm 0.88^{\mathrm{b}}$ & $\pm 0.50^{\mathrm{a}}$ & $\pm 0.84^{\mathrm{b}}$ & $\pm 0.90^{\mathrm{a}}$ \\
\hline Cholesterol BCH & 65.46 & 67.28 & 86.22 & 89.80 \\
mg/100 ml & \pm 1.00 & \pm 0.98 & \pm 5.82 & \pm 5.31 \\
\hline Triglyceride BTG & 27.00 & 20.86 & 22.28 & 27.66 \\
mg/100ml & \pm 2.67 & \pm 1.96 & \pm 1.08 & \pm 1.43 \\
\hline
\end{tabular}

abc, different letters in the same row denoted significant differences between experimental groups at level $\mathbf{P}<0.05$.

Results demonstrated a decrease in total protein concentration in rams and buck groups as compared with lambs and kids groups. This result is in agreement with other studies [18].It seems reasonable that daily diet requirements of young animals were almost enough met through their allowances of diet can it have from farm or the pasture, animals are probably compensating their nutritional need from fallen leaves' trees, grains and the dried pasture found within the small forests in the farm or supplemented [3]. Although disagreement with some researchers [22] who reported that regardless of cold stress, in the young animals blood protein is less than adults due to age effect reared to

Volume 6 Issue 1, January 2017

www.ijsr.net

Licensed Under Creative Commons Attribution CC BY 


\section{International Journal of Science and Research (IJSR) \\ ISSN (Online): 2319-7064 \\ Index Copernicus Value (2015): 78.96 | Impact Factor (2015): 6.391}

the reduction in globulins synthesis during the early stages of life.Total blood glucose was not significantly affected by cold stress between this type of animal,this result agrees with findings of [31], revealed the influence of cold stress on blood glucose, cold stress had remarkable influence on the glucose level in all animals that probably involves more intensive energy metabolism to keep body temperature. The urea level in the studied shows that sheep and goat (adults) had higher values than the other young breeds. The high level of serum urea might be attributed to excessive tissues protein catabolism associated with protein deficiency[32]. The serum total cholesterol concentration increased in adult groups insignificantly in cold winter However, is result agreed with that obtained by [31]who demonstrated that the quality of food available has an apparent impact on serum cholesterol concentration in these animals. Likewise, the level of blood serum cholesterol was not affected by animals'ages [13]. Results also revealed that higher blood triglyceride BTG concentration was detected in group of lambs as compared with rams, and has not followed the same direction as Cholesterol, similar finding was reported by [9]. While, in goat the result concerned blood triglyceride was upsides as compared with sheep groups, due to increasing requirement of energy maintenance in kids as compared with buck, these values determined in the present study correspond to those described by other research [33]. Regardless, the differences between breeds in all parameters the difference revered to the type of animals[30].In Conclusion, Hematological and biochemical parameters can be used to assess the health as well as the physiological status of farm animals under consideration. Changes of these parameters have been studied in sheep and goats. There is variation in the hematological or biochemical parameters as observed between breeds and ages in farm animals. These differences have further underlined the need to establish appropriate physiological baseline values for livestock in Iraq which could help in realistic evaluation of the management practice, nutrition, diagnosis of health as well as in determining the physiological status of farm animals.

\section{Acknowledgement}

I express my thanks and appreciation to the college of veterinary medicine, management of animal field and all researchers.

\section{References}

[1] Ovuru, S. S. andEkweozor, I. K. E. (2004). Haematological changes associated with crude oil ingestion in experimental rabbits. African Journal of Biotechnology, 3(6): 346-348.

[2] Alam, M. M., Hashem, M. A., Rahman, M. M., Hossain, M. M., Haque, M. R.,Sobhan, Z. and Islam, M. S. (2011).Behavior, Physiological And Blood Parameters Of Goat Journal of Agricultural Science, 22(1 and 2): $37-45$.

[3] Ouanes, I., Abdennour, C. and Aouaidjia,N. (2011).Effect of cold winter on blood biochemistry of domestic sheep fed natural pasture.Annals of Biological Research, 2(2):306-313

[4] Hatfield, P.G., Hopkins, J.A., Ramsey, W.S. and Gilmore, A. (1998) Effects of level of protein and type of molasses on digesta kinetics and blood metabolites in sheep. Small Ruminant.Research. 28(2): 161-170.

[5] Hoffman, P.C., Esser, N.M., Baumen, L.M., Denzine, S.L., Engstrom, M. and Chester- Jones, H. (2001). Short communication: Effect of dietary protein on growth and nitrogen balance of Holstein heifers. Journal Dairy Science, 84 (4): 843- 847.

[6] AL-Musawi,J. E. (2015).Effect of adding sunflower oil in the ration on some productive traits in Awassi ewes, Iraqi Journal Veterinary Medicine,39 (2):108-112.

[7] Doreau, M. and Ferlay, A. (1994).Effect of dietary lipids on nitrogen metabolism in the rumen: a review. Livestock Production Sci.,43: 97-110.

[8] Roubies, N.,Panousis, N.,Fytianou, A. Katsoulos, P. D.,Giadinis, N. and Karatzias, H. (2006). Effects of age and reproductive stage on certain serum biochemical parameters of Chios sheep underGreek rearing conditions. Journal Veterinary Medicine.A Physiol. Pathol.Clin. Med., 53: 277-281.

[9] Smith, M. C., Sherman, D. M. (2009).Goat Medicine.Second Edition. Wiley Blackwel Inc. USA.

[10] Ghergariu, S.,Rowlands, G.J., Pop, N. and Moldova, A. (1984). A Comparative Study of Metabolic Profiles obtained in Dairy Herds in Romania. British Veterinary Journal, 140: 600-608.

[11] Tambuwal, F. M.,Agale, B. M.andBangana, A. (2002). Haematological and serum biochemical values of apparently healthy red Sokoto goats. Proceeding of 27th Annual Conference of Nigerian Society of Animal Production.Pp: 50-53.

[12] Peccione,G., Caola, G., Giannetto1, C., Grasso, F., CalanniRunzo, S., Zumbo, A. and Pennisi, P. (2009).Selected biochemical serum parameters in ewes during pregnancy, post-parturition, lactation and dry period.Animal Sci. Papers and Reports., 27(4): 321-330.

[13] Doutamia, G. N. and Ganda, K. (2005) .Haematological and serum biochemical characterisation of small ruminants of Tchad. Revue du MédVéter., 156(4): 202-206.

[14] Baiden, R.Y., Rhule, S. W. A., Otsyina, H. R., Sottie, E. T. and Ameleke, G. (2007), Livest Res RurDevel", 19(3), Retrieved July 19, 2010, from http://www.lrrd.org/lrrd19/3/ baid 19035.htm

[15] Mmereole, F. U. C. (2008). The Effects of Replacing Groundnut Cake with Rubber Seed Meal on the Haematological and Serological Indices of Broilers.International Journal of Poultry Science, 7(6): 622-624.

[16] Isaac, L. J., Abah, G., Akpan, B.,and Ekaette, I. U. (2013). Haematological properties of different breeds and sexes of rabbits.Proceedings of the 18th Annual Conference of Animal Science Association of Nigeria.Pp: $24-27$.

[17] Bengamin, M.M. (1978). Online of veterinary clinical pathology 2nd edition, Iowa state University Press, Iowa U.S.A. Pp: 35-105.

[18] Jain, N.C. (1986). Haemotological Techniques in: Schalami's veterinary Haematology. Lea and FebigerphiladelphiaPp:20-86.

[19] Mohamed, S.S. and Abdelatif, A.M. (2010). Effects of Feeding and Season on Thermoregulation and Semen Characteristics in Desert Ram (Ovisaries). Global Veterinaria, 4(3): 207-215. 


\section{International Journal of Science and Research (IJSR) \\ ISSN (Online): 2319-7064}

Index Copernicus Value (2015): 78.96 | Impact Factor (2015): 6.391

[20] Mohamed, S. S.,Abdelatif, A. M. andAdam, A.A. (2012). Effects of Exposure to Solar Radiation on Thermoregulation and Semen Characteristics of Sudanese Desert Rams (Ovisaries). Global Veterinaria, 9(4): 502-507.

[21] Palterson, T. B., Shrode, R. R., Kunkel, H. O.,Leghton, R. E. and Rupel, I. W. (1960). variation in certain blood components of Holstein and Jersey Cows and their relationship to daily range in rectal temperature and milk and butter futproduction journal Dairy Science. 43:1263-1274.

[22] Isidahomen, E. C., Ikhimioya, I.,Njidda, A.A. and Okoruwa, M. I. (2010). Haematological parameters and Blood chemistry of different species of Ruminant animals in Humid Tropical environment.Nigerian Journal of Agriculture and forestry (NJAF). 3(1) 85-90.

[23] Kopp, R. and Hetesa, J. (2000). Changes of Haemotological studies in adolescent breeding cocks.Acta Vet. Brno, 69:189-194.

[24] Adejumo, D.O. (2004). Performance, organ development and Haematological of Rats ted sole diets of graded levels of cassava flour and soybean flour (soy gari) as substitutes for energy and protein concentrates. Trop. Journal Animal Science, 7:57-63.

[25] Schalm, O. W., Jain, N. C. and Carrol, E. J. (1975). Veterinary Haematology.3rd edition Lea Febiger Philadelphia USA.Pp: 13-167.

[26] Addas, P. A.,Midau, A. and Babale, D.M.(2010).Haemato-biochemical findings of indigenous goats in Mubi Adamawa State Nigeria.Journal. Agriculture Social Science, 6:14-16.

[27] Radostits, O. M., Blood, D. C.and Gay, C. C. (1994). Veterinary Medicine: A textbook of disease of cattle, sheep, pigs, goats and horses W B Saunders Co. $8^{\text {th }}$ ed., Pp: 304.

[28] Olayemi, F. O., Farotimi, J. O.and Fagbohun, O. A. (2000). Haematology of the West African Dwarf Sheep under Two Different Management Systems in Nigeria. African Journal of Biomedical Research, 3(2):197-198.

[29] Njidda, A. A., Hassan I. T. and Olatunji, E. A. (2013). Haematological and Biochemical Parameters of Goats of Semi Arid Environment Fed On Natural Grazing Rangeland of Northern Nigeria. Journal of Agriculture and Veterinary Science, 3(2): 1-8.

[30] Etim, N.N., Williams, M. E.,Akpabio, U.andOffiong, E. E. A. (2014).Haematological Parameters and Factors Affecting Their Values. Agricultural Science, 2(1): 3747.

[31] Hassan,S. A. and Hassan,K. M. (2009).Factors effecting medicinal plants supplementation on some blood parameters of karadi lambs. 2-Effect of increasing level of rumen degradable nitrogen.Diyala Agricultural Science Journal, 1(2): 13-23.

[32] Oduye, O.O. and Adedevon, B.K.(1976). Biochemical values of apparently Normal Nigerian sheep. Nigerian Veterinary Journal. 5(1):43-50.

[33] Mahr,U.N., Muhammad, Qamar,B. and Muhammad,A.F. (1999). Effect of Temperature Stress on Nutrient Utilization and Different physiological Functions ofRuminant Animals, Int.JournalAgricultural Biology, 15:174 -178.

Volume 6 Issue 1, January 2017 www.ijsr.net 